\title{
A MODEL BASED METHOD FOR COMPARING THE PROPERTIES OF SOME METAL-Ta2 $\mathrm{O}_{5} / \mathrm{SiO}_{2}-\mathrm{Si}$ STRUCTURES
}

\author{
Nenad Novkovski ${ }^{1,2}$ \\ ${ }^{1}$ Institute of Physics, Faculty of Natural Sciences and Mathematics, Ss. Cyril and Methodius University, \\ Skopje, Republic of Macedonia \\ ${ }^{2}$ Research Center for Environment and Materials, Macedonian Academy of Sciences and Arts, \\ Skopje, Republic of Macedonia \\ e-mail: nenad@iunona.pmf.ukim.edu.mk
}

Oxygen annealed radio frequency (RF) reactively sputtered and thermally grown (thermal) $\mathrm{Ta}_{2} \mathrm{O}_{5}$ films on silicon were comparatively studied by using combination of $C-V$ and $I-V$ measurements and the previously developed comprehensive model for the metal- $\mathrm{Ta}_{2} \mathrm{O}_{5} / \mathrm{SiO}_{2}-\mathrm{Si}$ structures. Dielectric properties of separate layers were extracted by comparing the experimental and the theoretical results. It is found that the net leakage properties of the $\mathrm{Ta}_{2} \mathrm{O}_{5}$ layer are significantly better in the case of RF than thermal, particularly in the case of the Au gate. Excessive growth of the $\mathrm{SiO}_{2}$ layer of about $0.3 \mathrm{~nm}$ in the case of $\mathrm{RF}$ films leads to an unwanted increase of the equivalent oxide thickness. Appropriate interface engineering is required in order to prevent the $\mathrm{SiO}_{2}$ excessive growth during the oxygen annealing. Such a growth can reduce the beneficial effects of the annealing on the net properties of $\mathrm{Ta}_{2} \mathrm{O}_{5}$ films obtained by RF.

Key words: high permittivity dielectrics; conduction in dielectrics; leakage currents model

\section{INTRODUCTION}

$\mathrm{Ta}_{2} \mathrm{O}_{5}$ films are nowadays extensively investigated for various applications, such as coatings for gravitational-wave detectors [1], multilayer stacked electrode in organic light-emitting diodes [2], resistive switching memories [3], gapless-type atomic switches [4], photocatalysts [5] etc. Ultrathin $\mathrm{Ta}_{2} \mathrm{O}_{5}$ films are particularly important as a new dielectric material for DRAM capacitors, because of their outstanding properties [6-9], such as high dielectric permittivity, high breakdown fields and low leakage current densities. The oxygen anneal of RF sputtered $\mathrm{Ta}_{2} \mathrm{O}_{5}$ films at high temperatures is found to be highly beneficial for their insulating properties $[10,11]$. It significantly increases the dielectric constant, reduces the fixed charge $Q_{\mathrm{f}}$ (as low as $10^{10} \mathrm{~cm}^{-2}$ ), reduces the leakage currents, and in- creases the breakdown field [8]. Pure oxygen ion assisted deposition provides similar improvements [12]. The fabrication of the insulating layer in the case of thermal growth [9] and RF-sputtering followed by oxygen anneal [8] is accompanied by unintentional formation of a silicon dioxide layer, and hence the insulating film has to be treated as a stacked layer. In $[13,14]$ we proposed and used a comprehensive model describing the leakage currents of thus obtained $\mathrm{Ta}_{2} \mathrm{O}_{5} / \mathrm{SiO}_{2}$ stacked layers. It has been later generalized for different similar structures [15].

In the present work we study comparatively the RF-sputtered and thermally grown tantalum pentoxide films on silicon by using the model described in [14], in order to compare the impact of the discussed technologies on the properties of separate layers. 


\section{EXPERIMENTAL}

Chemically cleaned p-type (100) $15 \Omega \cdot \mathrm{cm} \mathrm{Si}$ wafers were used as substrates. Some of the $\mathrm{Ta}_{2} \mathrm{O}_{5}$ films were deposited at $220{ }^{\circ} \mathrm{C}$ by radio frequency (RF) reactive sputtering of $99.99 \%$ pure Ta in a gas mixture of $\mathrm{Ar}$ and $\mathrm{O}_{2}$. Other films were obtained by RF-sputtering of a Ta target in Ar atmosphere followed by thermal oxidation in dry $\mathrm{O}_{2}$ at $600^{\circ} \mathrm{C}$ (thermal). All the films were subsequently annealed in dry oxygen at $900{ }^{\circ} \mathrm{C}$ for $30 \mathrm{~min}$. The thickness of $\mathrm{Ta}_{2} \mathrm{O}_{5}$ and the refractive index were measured by ellipsometry $(\lambda=632.8 \mathrm{~nm})$. The obtained thickness was $d_{\mathrm{tp}}=50 \mathrm{~nm}$. The refractive index was typically 2.1 , approximately equal to the generally adopted value 2.2 .

Metal-Insulator-Semiconductor (MIS) capacitors with two different gate electrodes ( $\mathrm{Al}$ and $\mathrm{Au}$ ) were formed. $\mathrm{Al}$ and $\mathrm{Au}$ electrodes were deposited by thermal evaporation. Au electrodes were deposited onto the $\mathrm{Ta}_{2} \mathrm{O}_{5}$ film using shadow mask technique. The corresponding gate electrode area is $1.96 \times 10^{-3} \mathrm{~cm}^{2}$. The MIS capacitors for the Al top electrodes were defined using photolithography and have the active areas of $2.5 \times 10^{-3} \mathrm{~cm}^{2}$.

High frequency $(1 \mathrm{MHz}) C-V$ characteristics were measured by a HP 3284 A LCR-meter. For the quasi-static measurements a HP 4140 B picoammeter/voltage source was used, at a voltage ramp rate of $0.1 \mathrm{~V} / \mathrm{s}$.

$I-V$ characteristics were measured by a HP 4140 A picoammeter DC voltage source. Current was measured in steps of $0.1 \mathrm{~V}$, with a hold time of $5 \mathrm{~s}$, allowing for the obtainment of negligible displacement current, as it was confirmed by reversing the voltage range of the measurement. Repeated measurements in the ranges used in this work gave practically the same results, proving that the charge trapping during these measurements does not affect significantly the film properties.

\section{THEORY (SECTION III)}

The conduction mechanisms that are considered are:

1. For the $\mathrm{SiO}_{2}$ layer, hopping conduction along with direct tunneling through a trapezoidal barrier or Fowler-Nordheim tunneling through a triangular barrier, depending on the electric field in the layer $\left(E_{\mathrm{so}}\right)$. Tunneling current can be created by the electrons or the holes. The barrier for the tunneling of holes is substantially higher than the barrier for electrons. Different carriers from the silicon substrate produce this current: electrons in the case of gate positively biased and holes in the case of gate negatively biased. Hence, the current depends upon the gate polarity.

2. For tantalum pentoxide, Poole-Frenkel mechanism, that is bulk-limited, thus independent on the polarity.

Direct tunneling current density through the $\mathrm{SiO}_{2}$ layer $\left(J_{\mathrm{DT}}\right)$ is given by the following expression:

$$
J_{\mathrm{DT}}=\frac{q^{2}}{8 \pi h \Phi} E_{\mathrm{so}}^{2} \exp \left(-\frac{8 \pi \sqrt{2 m^{*} q \Phi^{3}}}{3 h E_{\mathrm{so}}}\left(1-\left(1-\frac{d_{\mathrm{so}}}{\Phi} E_{\mathrm{so}}\right)^{3 / 2}\right)\right)
$$

and Fowler-Nordheim tunneling current density by

$$
J_{\mathrm{FN}}=\frac{q^{2}}{8 \pi h \Phi} E_{\mathrm{so}}^{2} \exp \left(-\frac{8 \pi \sqrt{2 m^{*} q \Phi^{3}}}{3 h E_{\mathrm{so}}}\right),
$$

where $q$ is the electron charge, $h$ is the Planck's constant, $m^{*}$ is the effective tunneling mass of carriers in $\mathrm{SiO}_{2}, d_{\text {so }}$ is the thickness of $\mathrm{SiO}_{2}$ layer, $\Phi$ is the tunneling barrier height, and $E_{\mathrm{so}}$ is the electric filed in $\mathrm{SiO}_{2}$ layer.

Total leakage current density through the $\mathrm{SiO}_{2}$ layer $\left(J_{\mathrm{so}}\right)$ is given by

$$
J_{\mathrm{so}}=\sigma_{\mathrm{hc}} E_{\mathrm{so}}+\left\{\begin{array}{ll}
J_{\mathrm{DT}} & E_{\mathrm{so}}<\frac{d_{\mathrm{so}}}{\Phi} \\
J_{\mathrm{FN}} & E_{\mathrm{so}}>\frac{d_{\mathrm{so}}}{\Phi}
\end{array},\right.
$$

where $\sigma_{\mathrm{hc}}$ is the hopping conductivity in the $\mathrm{SiO}_{2}$ layer.

The voltage drop on the $\mathrm{SiO}_{2}$ layer $\left(V_{\text {so }}\right)$ is:

$$
V_{\mathrm{so}}=E_{\mathrm{so}} d_{\mathrm{so}} \text {. }
$$

Leakage current density due to the PooleFrenkel mechanism in the $\mathrm{Ta}_{2} \mathrm{O}_{5}$ layer $\left(J_{\mathrm{tp}}\right)$ is given by the following expression:

$$
J_{\mathrm{tp}}=\sigma_{\mathrm{tp}} E_{\mathrm{tp}} \exp \left(\frac{1}{k T} \sqrt{\frac{q^{3}}{\pi \varepsilon_{0} K_{\mathrm{T}}}} \sqrt{E_{\mathrm{tp}}}\right),
$$

where $E_{\mathrm{tp}}$ is the electric field in the $\mathrm{Ta}_{2} \mathrm{O}_{5}$ layer, $\sigma_{\mathrm{tp}}$ is temperature-dependent defect-related constant having dimensions of conductivity, $k$ is the Boltzmann constant, $\varepsilon_{0}$ is the dielectric constant of vacuum and $K_{\mathrm{T}}=n^{2}$ is the optical frequency dielectric constant ( $n$ is the refractive index) of $\mathrm{Ta}_{2} \mathrm{O}_{5}$. 

given by:

The voltage drop on the $\mathrm{Ta}_{2} \mathrm{O}_{5}$ layer $\left(V_{\text {tp }}\right)$ is

$$
V_{\mathrm{tp}}=E_{\mathrm{tp}} d_{\mathrm{tp}}
$$

where $d_{\mathrm{tp}}$ is the thickness of the $\mathrm{Ta}_{2} \mathrm{O}_{5}$ layer.

The two quantities that are computed simultaneously here are the oxide voltage:

$$
V_{\mathrm{ox}}=V_{\mathrm{tp}}+V_{\mathrm{so}}=d_{\mathrm{tp}} E_{\mathrm{tp}}+d_{\mathrm{so}} E_{\mathrm{so}},
$$

and the current density in steady state

$$
J=J_{\text {tp }}=J_{\text {so }} \text {. }
$$

Current density $J=J_{\text {so }}$ was computed for given field $E_{\mathrm{so}}$ in the silicon dioxide, then the field in $\mathrm{Ta}_{2} \mathrm{O}_{5}$ layer was computed as inverse function of current of $J_{\mathrm{tp}}=J$ and the oxide voltage determined with the use of the expression (6). Following typical values were used in computations: $m_{\mathrm{e}}^{*}=0.61$ $m_{0}-$ effective electron mass in $\mathrm{SiO}_{2}\left(m_{0}\right.$ denotes the mass of free electron), $m_{\mathrm{h}} *=0.51 m_{0}-$ effective hole mass in $\mathrm{SiO}_{2}$ and $K_{\mathrm{T}}=4.84$.

The voltage on the insulating stacked layer $\left(V_{\text {ox }}\right)$ was calculated by using relations involving the flatband voltage $\left(V_{\mathrm{fb}}\right)$, the gate voltage $\left(V_{\mathrm{g}}\right)$ and voltage drop in the semiconductor $\left(\varphi_{\mathrm{s}}\right)$ [16]

$$
V_{\mathrm{ox}}=V_{\mathrm{g}}-V_{\mathrm{fb}}-\varphi_{\mathrm{s}}
$$

The voltage drop in the semiconductor $\left(\varphi_{\mathrm{s}}\right)$ has been computed solving numerically the following equation [15]:

$$
E_{\mathrm{so}}= \pm \frac{\varepsilon_{\mathrm{s}}}{\varepsilon_{\mathrm{so}}} \sqrt{\frac{2 k T p_{0}}{\varepsilon_{\mathrm{s}} \varepsilon_{0}}\left[\left(\exp \left(-\frac{q \varphi_{\mathrm{s}}}{k T}\right)+\frac{q \varphi_{\mathrm{s}}}{k T}-1\right)+\frac{n_{i}^{2}}{p_{0}^{2}}\left(\exp \left(\frac{q \varphi_{\mathrm{s}}}{k T}\right)-\frac{q \varphi_{\mathrm{s}}}{k T}-1\right)\right]}
$$

where $\varepsilon_{\mathrm{s}}$ is the relative permittivity of $\mathrm{Si}(11.9), \varepsilon_{\mathrm{so}}$ is the relative permittivity of $\mathrm{SiO}_{2}$ (3.9), $\varepsilon_{0}$ is the permittivity of vacuum, $n_{\mathrm{i}}$ is the intrinsic concentration of carriers in $\mathrm{Si}\left(1.45 \times 10^{10} \mathrm{~cm}^{-3}\right)$ and $p_{0}$ is the steady state majority carrier (holes) concentration in p-type Si.

\section{RESULTS AND DISCUSSION}

The high-frequency ( $1 \mathrm{MHz}) C-V$ characteristics for all the considered samples are shown in Figure 1. It is visible that the capacitances in accumulation for RF samples are lower than those for thermal ones. The entire characteristics for RF are shifted towards the right compared to the thermal. Applying the standard procedures used for MOS structures, the equivalent oxide thickness $\left(d_{\mathrm{eq}}\right)$ [17], the fixed charge density $\left(Q_{\mathrm{f}}\right)[18]$ and the interface state density at midgap ( $\left.D_{\text {itm }}\right)$ [19]were computed. The results are shown in Table 1. Equivalent thicknesses of the RF films are significantly higher than those of the thermal ones. Fixed charge is positive in the case of the thermal films and negative in the case of RF. The interface state densities are of order of $10^{12} \mathrm{eV}^{-1} \mathrm{~cm}^{-2}$ and are significantly lower in the case of RF than thermal. Fixed charges of thermal films are about $4 \times 10^{11} \mathrm{~cm}^{-2}$, that is less positive than the value obtained for the films without oxygen anneal, $1.2 \times 10^{12} \mathrm{~cm}^{-2}$ [15]. RF films with the fixed charge of about $-1.5 \times 10^{12} \mathrm{~cm}^{-2}$ manifest similar shift toward the negative values compared to the unanealed RF films $\left(Q_{\mathrm{f}}=6 \times 10^{11} \mathrm{~cm}^{-2}\right)$ [15]. The oxygen annealing leads in some cases to negative values of $Q_{\mathrm{f}}$. It is certain that not only positively charged defects are reduced, but an important amount of negatively charged defects is created. This can be explained by the crystallization of the $\mathrm{Ta}_{2} \mathrm{O}_{5}$ layer, leading to broken bonds at the $\mathrm{Ta}_{2} \mathrm{O}_{5} / \mathrm{SiO}_{2}$ interface [20]. We have shown that the oxygen anneal at lower temperatures $\left(600 \div 850{ }^{\circ} \mathrm{C}\right)$ leads to very low fixed charges (as low as $10^{11} \mathrm{~cm}^{-2}$ ) [8]. Therefore, increasing the annealing temperature to $900{ }^{\circ} \mathrm{C}$ or above can have harmful effects on the fixed charge.

Table 1. Parameters extracted from the $C-V$ characteristics

\begin{tabular}{lcccc}
\hline Growth & Gate & $d_{\text {eq }}(\mathrm{nm})$ & $Q_{\mathrm{ox}}\left(\mathrm{cm}^{-2}\right)$ & $\begin{array}{c}D_{\text {itm }} \\
\left(\mathrm{eV}^{-1} \mathrm{~cm}^{-2}\right)\end{array}$ \\
\hline \multirow{2}{*}{ RF-sputtered } & $\mathrm{Al}$ & 8.7 & $-1.4 \times 10^{12}$ & $1.2 \times 10^{12}$ \\
& $\mathrm{Au}$ & 9.2 & $-1.6 \times 10^{12}$ & $2.0 \times 10^{12}$ \\
\multirow{2}{*}{ Thermal } & $\mathrm{Al}$ & 8.3 & $4 \times 10^{11}$ & $4.0 \times 10^{12}$ \\
& $\mathrm{Au}$ & 8.4 & $6 \times 10^{11}$ & $3.0 \times 10^{12}$ \\
\hline
\end{tabular}




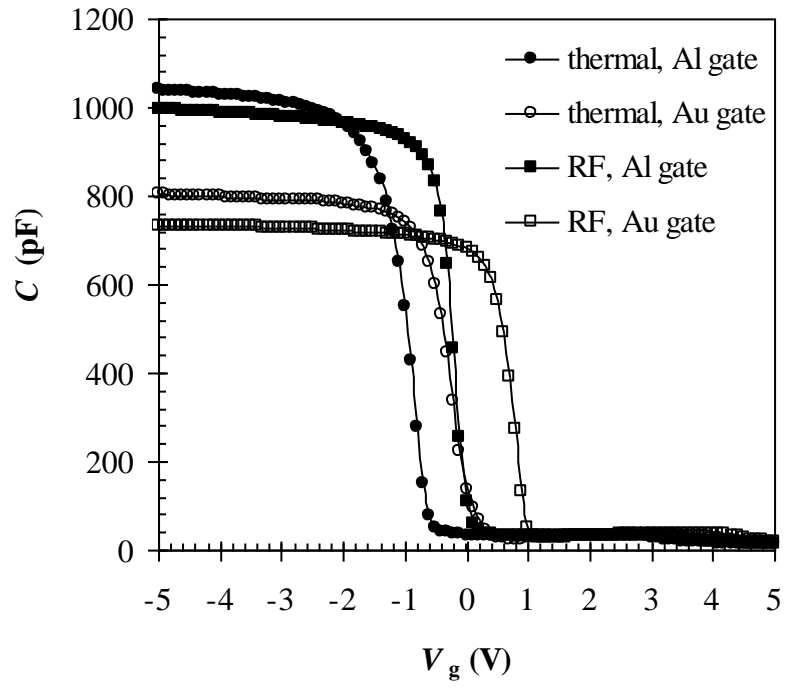

Figure 1. $C$ - $V$ characteristics of the MOS capacitors with areas of $0.0025 \mathrm{~cm}^{2}$ (Al gates) and $0.00196 \mathrm{~cm}^{2}$ (Au gates) containing thermally grown and RF-sputtered $\mathrm{Ta}_{2} \mathrm{O}_{5}$ films

The leakage current characteristics shown in Figures 2 and 3 were analyzed by using the model described in the Section III. Few of the parameters were fitted to obtain the matching between the theoretical and experimental results. These are the parameters influenced by the technological processes and not those that are accurately determined in the literature, listed in Section III. The parameters extracted by fitting the theoretical to the experimental results are given in Table 2 .

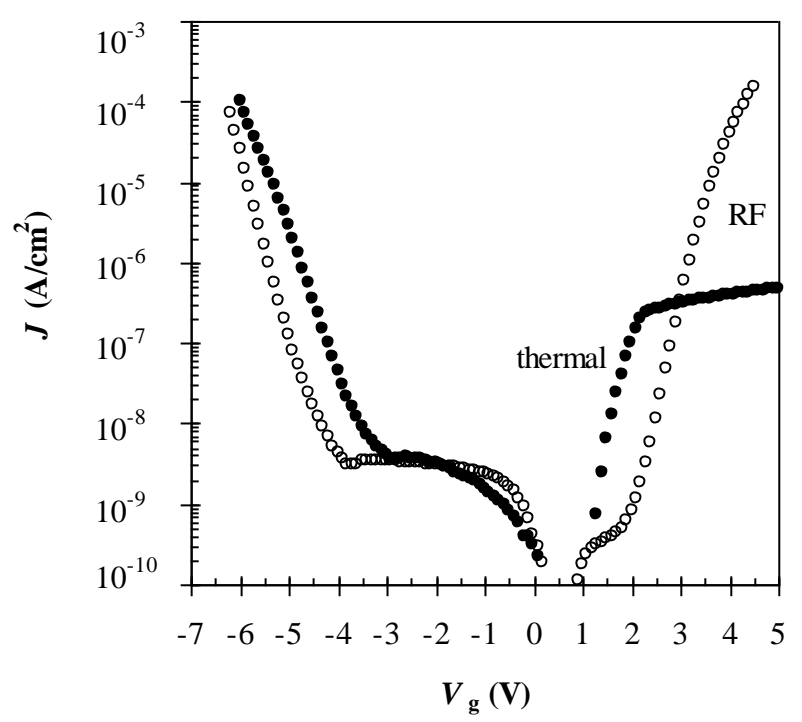

Figure 2. Leakage currents for MOS capacitors with $\mathrm{Al}$ gate containing thermally grown and RF-sputtered $\mathrm{Ta}_{2} \mathrm{O}_{5}$ films

Very good agreement between the theoretical and experimental results in the entire measurement region is obtained (Figure 4), justifying the use of the proposed model in the analysis. Saturated part for the positive gate is due to the strong inversion and is not described by this model.

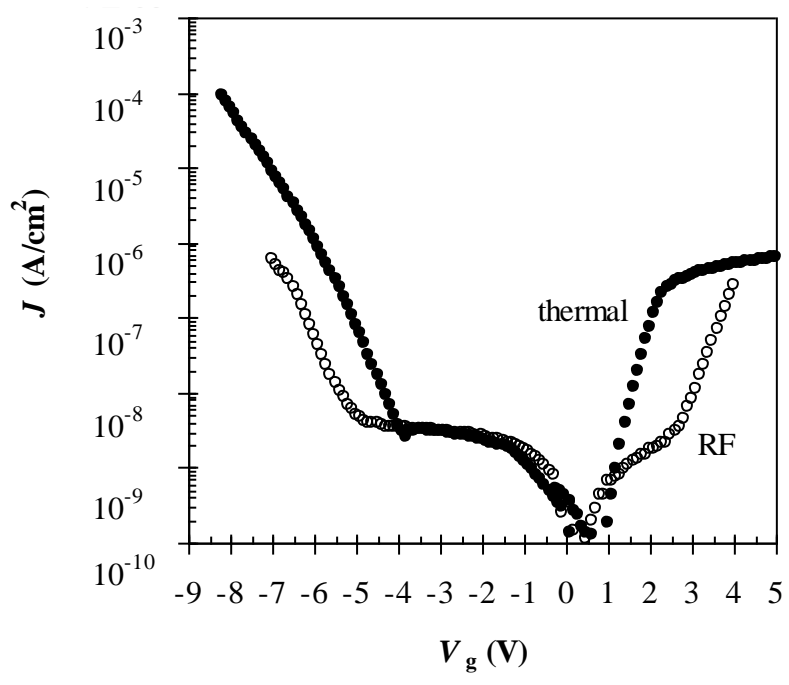

Figure 3. Leakage currents for MOS capacitors with $\mathrm{Au}$ gate containing thermally grown and RF-sputtered $\mathrm{Ta}_{2} \mathrm{O}_{5}$ films

The interfacial $\mathrm{SiO}_{2}$ layer thickness for thermal films is about $2.7 \mathrm{~nm}$, while for RF it is from $0.3 \mathrm{~nm}$ to $0.5 \mathrm{~nm}$ higher. Compared to the total thickness $(50 \mathrm{~nm})$ it is a very small value, but its contribution to the equivalent oxide thickness is significant. Barriers are practically equal to those for $\mathrm{SiO}_{2}$ films from literature [13]. There are some differences between the values of the $\mathrm{SiO}_{2}$ layer hopping conductivity for different samples, but they are comparable to the measurement error and can be disregarded. Thus, we can conclude that the quality of the $\mathrm{SiO}_{2}$ layer is practically the same for both processes and both gate materials.

The parameter $\sigma_{\mathrm{tp}}$ is the most influenced by the technology and the gate material, which describes the net leakage properties of the $\mathrm{Ta}_{2} \mathrm{O}_{5}$ layer. In the case of $\mathrm{Al}$ gate, $\sigma_{\mathrm{tp}}$ is 3 times lower for $\mathrm{RF}$ than thermal films, while for Au gate, it is 10 times lower for RF than thermal. In [13] we explained the difference between $\mathrm{Al}$ and $\mathrm{Au}$ gates by the creation of defects due to the reactivity of $\mathrm{Al}$ with $\mathrm{Ta}_{2} \mathrm{O}_{5}$. In the case of non-reactive Au gate, the obtained value of $\sigma_{\text {tp }}$ can be considered as intrinsic for the insulating material. Thus, the leakage factor for RF films is an order of magnitude lower than for thermal. In the case of $\mathrm{Al}$ gate, the difference between the RF and thermal films is less marked, because the majority of the defects responsible for the leakage are created by the reaction of the $\mathrm{Al}$ gate with the film and not during the growth of the insulating layer. 


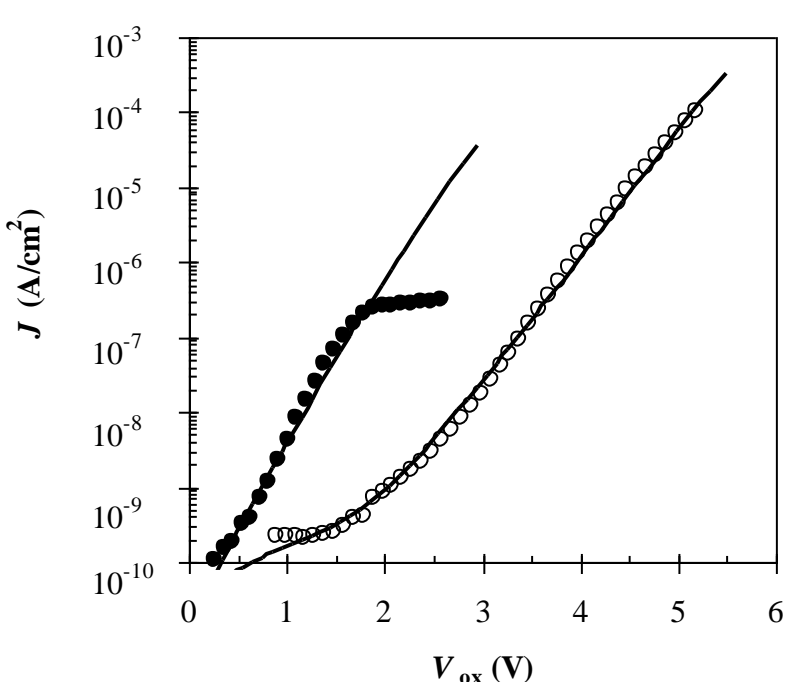

$\mathbf{a}$

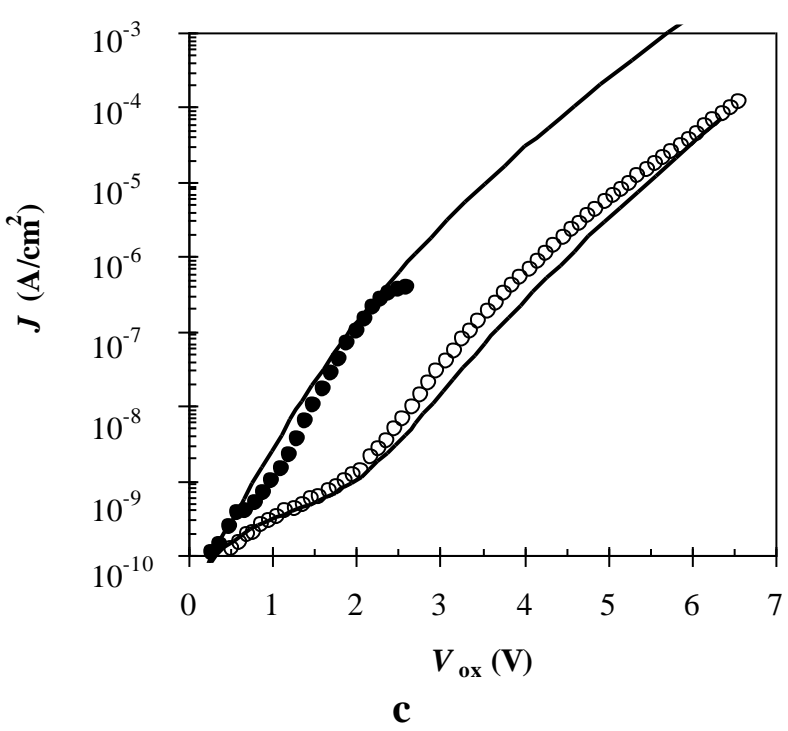

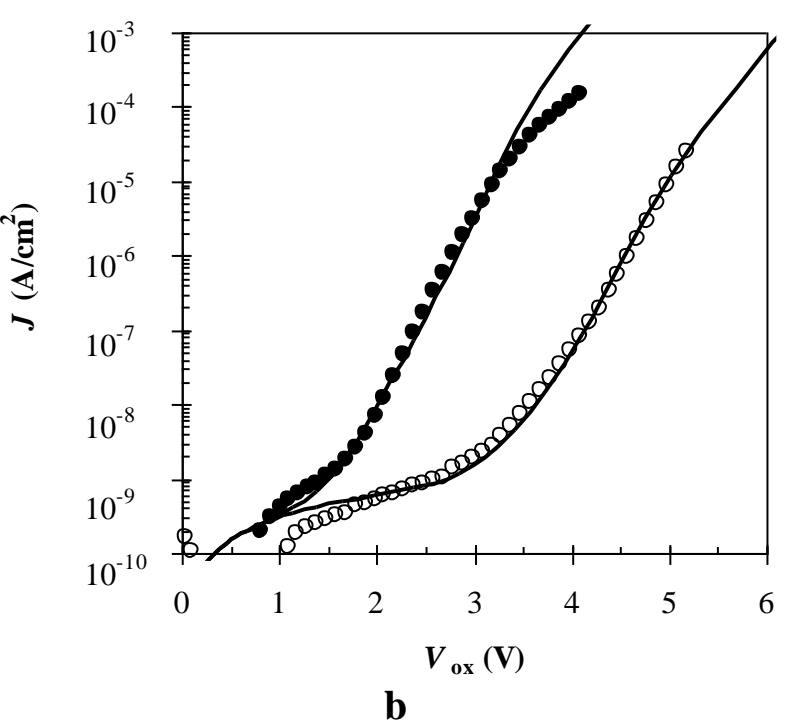

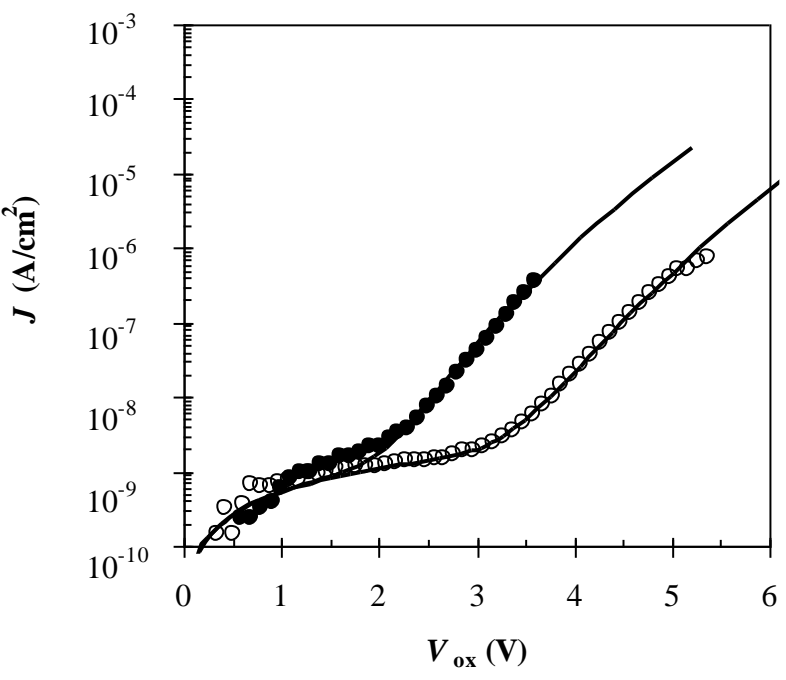

d

Figure 4. Experimentally obtained leakage currents versus oxide voltage for positive (closed circles) and negative gate (open circles) compared to the theoretical computations: a) thermally grown, Al gate, b) RF-sputtered, Al gate,

c) thermally grown, Au gate, d) RF-sputtered, Au gate

Table 2. Parameters extracted from the $I-V$ characteristics

\begin{tabular}{lcccccc}
\hline Growth & Gate & $\begin{array}{c}d_{\mathrm{so}} \\
(\mathrm{nm})\end{array}$ & $\begin{array}{c}\sigma_{\mathrm{hc}} \\
\left(\Omega^{-1} \mathrm{~cm}^{-1}\right)\end{array}$ & $\begin{array}{c}\sigma_{\mathrm{tp}} \\
\left(\Omega^{-1} \mathrm{~cm}^{-1}\right)\end{array}$ & $\begin{array}{c}\Phi_{\mathrm{e}} \\
(\mathrm{eV})\end{array}$ & $\begin{array}{c}\Phi_{\mathrm{h}} \\
(\mathrm{eV})\end{array}$ \\
\hline \multirow{2}{*}{ RF-sputtered } & $\mathrm{Al}$ & 3.02 & $9.0 \times 10^{-17}$ & $2.5 \times 10^{-11}$ & 3.15 & 4.70 \\
& $\mathrm{Au}$ & 3.20 & $1.8 \times 10^{-16}$ & $5.9 \times 10^{-15}$ & 3.15 & 4.30 \\
\multirow{2}{*}{ Thermal } & $\mathrm{Al}$ & 2.70 & $6.0 \times 10^{-17}$ & $8.2 \times 10^{-11}$ & 3.15 & 4.70 \\
& $\mathrm{Au}$ & 2.75 & $6.0 \times 10^{-17}$ & $6.6 \times 10^{-14}$ & 3.15 & 4.70 \\
\hline
\end{tabular}

Using the measured total thickness values $(d)$ and the obtained values for the $\mathrm{SiO}_{2}$ layer thickness $\left(d_{\mathrm{so}}\right)$ and the equivalent oxide thickness $\left(d_{\mathrm{eq}}\right)$, the effective oxide dielectric constant $\left(\varepsilon_{\mathrm{ef}}\right)$ and the net dielectric constant of the $\mathrm{Ta}_{2} \mathrm{O}_{5}$ layer $\left(\sigma_{\mathrm{tp}}\right)$ were computed. Their values are given in Table 3. All the values are close to these reported in literature [15]. The values obtained for Al gate are slightly higher than these for Au gate, for both RF and thermal. 
Table 3. Effective dielectric constant of the stack ( $\left.\varepsilon_{\mathrm{ef}}\right)$ and net dielectric constant of the tantalum pentoxide layer $\left(\sigma_{\mathrm{tp}}\right)$.

\begin{tabular}{lccc}
\hline Growth & Gate & $\varepsilon_{\text {ef }}$ & $\sigma_{\text {tp }}$ \\
\hline \multirow{2}{*}{ RF-sputtered } & $\mathrm{Al}$ & 22.5 & 34.8 \\
& $\mathrm{Au}$ & 21.1 & 32.3 \\
\multirow{2}{*}{ Thermal } & $\mathrm{Al}$ & 23.5 & 34.8 \\
& $\mathrm{Au}$ & 23.2 & 34.4 \\
\hline
\end{tabular}

\section{CONCLUSIONS}

Based on the use of a comprehensive model for leakage current in metal- $\mathrm{Ta}_{2} \mathrm{O}_{5} / \mathrm{SiO}_{2}-\mathrm{Si}$ structures it has been found thatthe oxygen anneal of RF-sputtered films leads to significantly better net leakage properties of the $\mathrm{Ta}_{2} \mathrm{O}_{5}$ layer, compared to the thermally grown. However, the thickness of the interfacial $\mathrm{SiO}_{2}$ layer for $\mathrm{RF}$ films is about $0.4 \mathrm{~nm}$ higher than this for thermal. Therefore, appropriate interface engineering in required in order to benefit from the outstanding net $\mathrm{Ta}_{2} \mathrm{O}_{5}$ layer without compromising the equivalent oxide thickness.

The use of the model of comparative analysis in description of the properties of separate layers, as is demonstrated in this work, provides in deep insight into the properties of the materials with reduced number of technological experiments compared to direct approach. Therefore, it is to be used in directed search of the technological solutions for materials with required properties.

Acknowledgement:The author is exceptionally grateful to Prof. Elena Atanassova from the Institute of Solid State Physics, Bulgarian Academy of Sciences, for providing the samples of very high quality studied in this work.

\section{REFERENCES}

[1] A. Amato, G. Cagnoli, M. Canepa, E. Coillet, J. Degallaix, V. Dolique, D. Forest, M. Granata, V. Martinez, C. Michel, L. Pinard, High-Reflection Coatings for Gravitational-Wave Detectors: State of The Art and Future Developments, J. Phys.: Conf. Ser., 957 (2018), pp. 012006-1-012006-7.

[2] J. Sohn, Y. Kwon, Y. Lee, C. Lee, Light outcoupling efficiency enhancement in organic lightemitting diodes using a multilayer stacked electrode with sol-gel processed $\mathrm{Ta}_{2} \mathrm{O}_{5}$. Opt. Exp., 25(2017), pp. 27886-27895.

[3] S. Ryu, S.K. Kim, B. J. Choi, Resistive switching of $\mathrm{Ta}_{2} \mathrm{O}_{5}$-based self-rectifying vertical-type resistive switchingmemory, J. Elec. Mat.47 (2018), pp.162-166.
[4] Yuki Shigeoka, TsuruokaTohru, Hasegawa Tsuyoshi, The rate limiting process and its activation energy in the forming process of a $\mathrm{Cu} / \mathrm{Ta}_{2} \mathrm{O}_{5} / \mathrm{Pt}$ gapless-type atomic switch, Jap. J. Appl. Phys., 57 (2018), pp. 035202.

[5] S. Sathasivam, B. A. Williamson, A. Kafizas, S. A. Althabaiti, A. Y. Obaid, S. N. Basahel, D. O. Scanlon, C.J. Carmalt, I. P. Parkin, Computational and experimental study of $\mathrm{Ta}_{2} \mathrm{O}_{5}$ thin films, The $J$. Phys. Chem.C,121(2017), pp. 202-210.

[6] U. Schroeder, K. Cho, S. Slesazeck, Materials for DRAM Memory Cell Applications, in Thin Films On Silicon: Electronic and Photonic Applications 8 (2017), pp. 369-401.

[7] A. P. Huang, P. K. Chu, Improvement of interfacial and dielectric properties of sputtered $\mathrm{Ta}_{2} \mathrm{O}_{5}$ thin films by substrate biasing and the underlying mechanism, J. Appl. Phys., 97 (2005), pp. $114106-$ 1-114106-5.

[8] E. Atanassova, N. Novkovski, A. Dimitrova, M. Pecovska-Gjorgjevich, Oxygen annealing modification of conduction mechanism in thin rf sputtered $\mathrm{Ta}_{2} \mathrm{O}_{5}$ on Si. Solid St. Electron., 46 (2002), pp.1887-1898.

[9] E. Atanassova, A. Paskaleva, N. Novkovski, and M. Georgieva, Conduction mechanisms and reliability of thermal $\mathrm{Ta}_{2} \mathrm{O}_{5}-\mathrm{Si}$ structures and the effect of the gate electrode, J. Appl. Phys., 97 (2005), pp. 094104-1-094104-11.

[10] L. Wang, H. Liu, Y. Jiang, X. Yang, D. Liu, Y. Ji, F. Zhang, D. Chen, Effects of hot-isostatic pressing and annealing post-treatment on $\mathrm{HfO}_{2}$ and $\mathrm{Ta}_{2} \mathrm{O}_{5}$ films prepared by ion beam sputtering, Optik-International Journal for Light and Electron Optics, 142 (2017), pp. 33-41.

[11] M. C. Sekhar, N. N. K. Reddy, H.S. Akkera, B. P. Reddy, V. Rajendar, S. Uthanna, S.H. Park, Role of interfacial oxide layer thickness and annealing temperature on structural and electronic properties of $\mathrm{Al} / \mathrm{Ta}_{2} \mathrm{O}_{5} / \mathrm{TiO}_{2} / \mathrm{Si}$ metal-insulator-semiconductor structure, J. All. Comp., 718 (2017), pp.104-111.

[12] J. Han, Q. Zhang, W Fan., G. Feng, Y. Li, A. Wei, R. Hu, Q. Gu, The characteristics of $\mathrm{Ta}_{2} \mathrm{O}_{5}$ films deposited by radio frequency pure oxygen ion assisted deposition (RFOIAD) technology, J. Appl. Phys., 121(2017), pp. 065302-1-065302-9.

[13] N. Novkovski and E. Atanassova, Injection of holes from the silicon substrate in $\mathrm{Ta}_{2} \mathrm{O}_{5}$ films grown on silicon, Appl. Phys. Lett., 85 (2004), pp. 3142-3144.

[14] N. Novkovski, E. Atanassova, A comprehensive model for the $I-V$ characteristics of metal$\mathrm{Ta}_{2} \mathrm{O}_{5} / \mathrm{SiO}_{2}-\mathrm{Si}$ structures, Appl. Phys., A, 83 (2006), pp. 435-445. 
[15] N. Novkovski, Physical modeling of electrical and dielectric properties of high- $\kappa \mathrm{Ta}_{2} \mathrm{O}_{5}$ based MOS capacitors on silicon, FactaUniversitatis, Series: Electronics and Energetics, 27 (2014), pp. 259-273.

[16] K. Maitra, N. Bhat, Analytical approach to integrate the different components of direct tunneling current through ultrathin gate oxides in $n$-channel metal-oxide-semiconductor field-effect transistors, J. Appl. Phys., 93 (2003), 1064-1068.

[17] E. Atanassova, T. Dimitrova, Thin $\mathrm{Ta}_{2} \mathrm{O}_{5}$ layers on $\mathrm{Si}$ as an alternative to $\mathrm{SiO}_{2}$ for high density DRAM applications, in Handbook of surfaces and interfaces of materials, Edited by Hari Singh Naiwa, Volume 4: Solid thin films and layers, Academic Press, San Diego, (2001),pp. 439-479.

[18] S. M. Sze and K. K. Ng, Physics of Semiconductor Devices, 3rd Edition, John Wiley \& Sons, New York,2007.

[19] D. K. Schroder, Semiconductor Material and Device Characterization, 3rd Edition, John Wiley \& Sons (2006).

[20] E. Atanassova, A. Paskaleva, Challenges of $\mathrm{Ta}_{2} \mathrm{O}_{5}$ as high- $\kappa$ dielectric for nanoscale DRAMs, Microelectronics Reliability, 47 (2007), pp. 913-923.

\title{
МОДЕЛЕН МЕТОД ЗА СПОРЕДБА НА СВОЈСТВАТА НА СТРУКТУРИ ОД ТИПОТ МЕТАЛ-Та $\mathbf{O}_{2} \mathrm{O}_{5} / \mathrm{SiO}_{2}$-Si
}

\author{
Ненад Новковски \\ Институт за физика, Природно-математички факултет, Универзитет,„в. КирилиМетодиј“, Скопје, \\ РепубликаМакедонија \\ Истражувачки центар за животна средина и материјали, \\ Македонска академија на науките и уметностите, Скопје, Република Македонија
}

Филмови од $\mathrm{Ta}_{2} \mathrm{O}_{5}$ врз силициум добиени со високофреквенциско реактивно распрашување и термички третирани во кислород (РФ) и филмови од $\mathrm{Ta}_{2} \mathrm{O}_{5}$ термички израснати (thermal) ce проучувани компаративно со употреба на $C$ - $V$ and $I-V$ и претходно развиениот сеопфатен модел за структури метал- $\mathrm{Ta}_{2} \mathrm{O}_{5} / \mathrm{SiO}_{2}-\mathrm{Si}$. Преку споредба на експерименталните со теориските резултати сеопределени диелектричните својства на одделните слоеви. Најдено е дека чистите својства за претекување низ слоевите од $\mathrm{Ta}_{2} \mathrm{O}_{5}$ се значајно подобри во случајот на РФ отколку кај термички израснатите филмови, особено во случајот на горната електрода од Аи. Додатниот пораст на слојот од $\mathrm{SiO}_{2}$ за околу $0,3 \mathrm{~nm}$ во случај на РФ-филмовите води до несакан раст на еквивалентната дебелина на оксидот. Потребно е да се направи соодветно нагодување на интерфејсот со цел да се избегне претеранпораст на $\mathrm{SiO}_{2}$,едновремено користејќи ги подобрените чисти својства на филмовите од $\mathrm{Ta}_{2} \mathrm{O}_{5}$ добиени со РФ.

Клучни зборови: диелектрици со висока пермитивност; спроводливост низ диелектрици; модел за струите на протекување 